\author{
B. Helliot $\cdot$ B. Panis $\cdot$ Y. Poumay $\cdot$ R. Swennen \\ P. Lepoivre $\cdot$ E. Frison
}

\title{
Cryopreservation for the elimination of cucumber mosaic and banana streak viruses from banana (Musa spp.)
}

Received: 17 September 2001 / Revised: 20 February 2002 / Accepted: 26 February 2002 / Published online: 5 April 2002

(C) Springer-Verlag 2002

\begin{abstract}
The utilisation of cryopreservation for the eradication of cucumber mosaic virus (CMV) or banana streak virus (BSV) from Musa spp. was investigated. Banana plants, cv. Williams (AAA, Cavendish subgroup), were mechanically infected with CMV or naturally infected with BSV, and proliferating meristems were produced from the infected plants. Excised meristematic clumps were cryopreserved through vitrification using PVS-2 solution. The health status of regenerated in vitro plants was first checked by means of ELISA. The putative virus-free material was subsequently tested a second time following greenhouse acclimatisation. The frequency of virus eradication for CMV and BSV was $30 \%$ and $90 \%$, respectively, following cryopreservation. In comparison, the frequency of virus-free plants regenerated directly from highly proliferating meristems, corresponding to a spontaneous eradication rate, reached $0 \%$ and $52 \%$ for $\mathrm{CMV}$ and $\mathrm{BSV}$, respectively. The conventional meristem culture resulted in 0\% CMV-free plants and 76\% BSV-free plants, while the cryoprotective treatment resulted in $2 \% \mathrm{CMV}$-free plants and $87 \%$ BSV-free plants. To understand the mode of action of cryopreservation for the eradication of viral particles, we examined the structure of the meristem tips by light microscopy. The cryopreservation method used only allowed survival of small areas of cells located in the meristematic dome and at the base of the primordia.
\end{abstract}

Communicated by P. Debergh

B. Helliot · P. Lepoivre $(\square)$

Plant Pathology Unit, Gembloux Agricultural University, 5030 Gembloux, Belgium

e-mail: lepoivre.p@fsagx.ac.be

Fax: +32-16-321993

B. Panis $\cdot$ R. Swennen

Laboratory of Tropical Crop Improvement, K.U. Leuven,

3001 Leuven, Belgium

Y. Poumay

Department of Histology-Embryology, FUNDP,

5000 Namur, Belgium

E. Frison

INIBAP/IPGRI, 34397 Montpellier, France
Keywords Banana streak virus - Cucumber mosaic virus . Cryopreservation $\cdot$ Musa $\cdot$ Virus eradication

Abbreviations $B A$ : $\mathrm{N}^{6}-$ Benzyladenine

$B S V$ : Banana streak virus - IAA: Indole-3-acetic acid .

$C M V$ : Cucumber mosaic virus

\section{Introduction}

For many crops, cryopreservation is currently being applied to overcome the serious limitations encountered by traditional germplasm conservation strategies in field, seed and in vitro culture collections. Conservation at ultra-low temperatures, usually at $-196^{\circ} \mathrm{C}$, which is the temperature of liquid nitrogen, allows the long-term and contamination-free storage of plant genetic resources. In 1997, Brison and co-workers demonstrated for the first time that cryopreservation can not only be used for germplasm conservation but also for virus eradication: cryopreservation resulted in 50\% virus-free in vitro plants from plum shoots infected with plum pox virus (Brison et al. 1997).

Banana plants (Musa genus) are cultivated on five continents in about 120 countries, mainly tropical and subtropical, and they provide a staple food source for millions of people (Frison and Sharock 1999). However, banana production is threatened by various biotic agents (bacteria, fungi or viruses) such as the cucumber mosaic virus or banana streak virus (Lockhart and Jones 2000). CMV, which has a spherical particle of $28-30 \mathrm{~nm}$ in diameter containing a ssRNA, is naturally transmitted by aphid vectors or by seed. Hu et al. (1995) have identified banana viral isolates as belonging to the subgroup I, DTL serotype. Symptoms depend on the strain of the virus pathogen and temperature. Thus, mild or severe chlorosis and necrosis on leaves and pseudostem can be observed, causing significant yield losses. The virion of BSV is a non-enveloped bacilliform $(135-150 \times 30 \mathrm{~nm}$ in size) containing a dsDNA genome of $7.4 \mathrm{~kb}$ (Lockhart and Olzewski 1993). This badnavirus is transmitted by 
Fig. 1 a, b Production of proliferating meristem clumps (cv. Williams ITC. 0570): left to right proliferating cultures after zero, one, three and seven subcultures on p4 medium (a) and an ideal actively proliferating meristem culture (b). c, d Light microscopy of an actively proliferating meristematic clump $(\times 4)$ containing several apical domes without the protection of a primordium compared to meristem excised from an in vitro plant $(\times 10)$ with one apical dome protected by several primordia (d). $\operatorname{Pr}$ Primordium, $T$ tunica, $C$ corpus
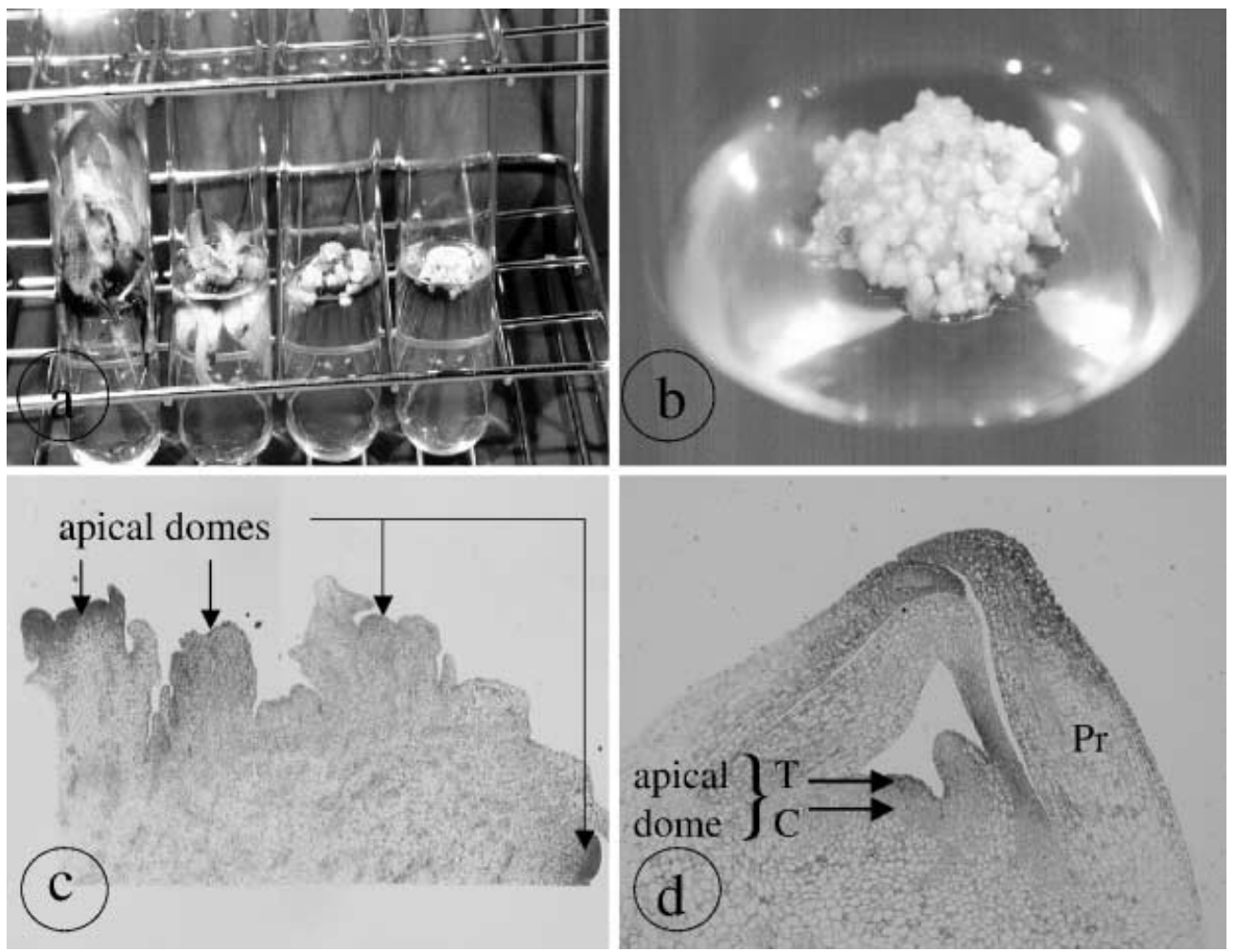

mealy bugs, and mechanical inoculations have been unsuccessful (Lockhart and Jones 2000). BSV is responsible for sparse or concentrated chlorotic streaks on leaves, leading in certain cases to lethal chlorosis. Recently, Harper et al. (1999) have shown that BSV genomic sequences are integrated into the genomic DNA of Musa, which could give rise to episomal BSV infection in the case of the banana containing a B genome.

To date, reports on virus elimination from infected banana plants are very scarce. For example, heat treatment combined with meristem culture has been successful for CMV eradication (Berg and Bustamante 1974; Gupta 1986), while no eradication treatment has been reported for BSV. We previously reported on the successful cryopreservation of proliferating meristems of different accessions of banana (Panis et al. 1996, 1998). Here we report on the efficiency of cryotherapy in Musa in comparison to virus eradication by meristem culture alone.

\section{Materials and methods}

Plant material

\section{Starting material}

The dessert banana cultivar Williams BSJ (ITC. 0570, AAA Cavendish subgroup) (Daniells et al. 2001) was provided by the INIBAP Transit Center (ITC, Leuven, Belgium).

\section{Production of proliferating meristem clumps}

In vitro shoots were placed on $\mathrm{p} 4$ medium: MS (Murashige and Skoog 1962) semi-solid medium supplemented with $100 \mu M$ BA,
$1 \mu M$ IAA and $3 \%$ sucrose. The material was subcultured every 1-2 months (Fig. 1a), and only small white clumps of highly proliferating meristems were selected and transferred to fresh medium (Fig. 1b).

\section{CMV transmission}

The CMV isolate (subgroup DTL), which originates from Colombia, was mechanically transmitted to cv. Williams banana plants, while naturally BSV-infected plants of the same cultivar were kindly provided by J. Thomas (QDPI, Australia).

Leaves of $\mathrm{CMV}$-infected tobacco were ground in a phosphate buffer $\left(0.05 \mathrm{M} \mathrm{KH}_{2} \mathrm{PO}_{4}, 0.01 M\right.$ DIECA, $\mathrm{pH}$ 7.2) using carborundum $(75 \mathrm{mg} / \mathrm{ml})$ as an abrasive. The sap was applied for $10 \mathrm{~min}$ onto leaves of cv. Williams plants that were subsequently kept under conditions of low light for $12 \mathrm{~h}$. The leaves were then rinsed with water and the plants kept under the low-light conditions for $4-5 \mathrm{~h}$ before being placed under normal growing conditions [temperature: $23^{\circ} / 18^{\circ} \mathrm{C}$ (day/night); photoperiod: $16 / 8 \mathrm{~h}$ (light/dark); light intensity: $39 \mu \mathrm{mol} / \mathrm{m}^{2} / \mathrm{s}$ ]

\section{Cryopreservation}

\section{Preculture}

White meristematic clumps (4 $\mathrm{mm}$ in diameter) containing at least four apical domes (Fig. 1c) were transferred onto the preculture medium. This medium is identical to $\mathrm{p} 4$ medium but with a BA concentration of $10 \mu \mathrm{M}$ BA and a sucrose concentration of $0.4 M$. These cultures were maintained for 2 weeks.

\section{Loading}

Sucrose-precultured meristematic clumps (1.5-3 $\mathrm{mm}$ in diameter) were isolated and kept for $20 \mathrm{~min}$ in a filter-sterilised loading solution ( $2 M$ glycerol and $0.4 M$ sucrose dissolved in MS medium, $\mathrm{pH}$ 5.8) at room temperature. 
The loading solution was replaced by ice-cooled and filter-sterilised PVS-2 solution (Sakaï et al. 1990) containing 30\% (3.26 M) glycerol, $15 \%(2.42 M)$ ethylene glycol, 15\% (1.9 $M)$ DMSO and $0.4 M$ sucrose dissolved in MS medium (pH 5.8). Meristematic clumps were immersed in the PVS-2 solution for $120 \mathrm{~min}$ at $0^{\circ} \mathrm{C}$, transferred to 2-ml cryotubes and immersed into liquid nitrogen for a minimum of $1 \mathrm{~h}$

\section{Thawing and deloading}

Tubes containing meristematic clumps were rapidly thawed in a warm water bath $\left(40^{\circ} \mathrm{C}\right)$ for $80 \mathrm{~s}$. The PVS-2 solution was replaced by the filter-sterilised deloading solution (1.2 M sucrose dissolved in MS medium, $\mathrm{pH}$ 5.8) for $15 \mathrm{~min}$ at room temperature.

\section{Recovery}

Control meristematic clumps (C) were loaded, dehydrated and deloaded but not frozen, and frozen meristems (F) were taken from the deloading solution and placed in $9-\mathrm{cm}$ plastic petri dishes onto two sterile filter papers on top of semi-solid hormone-free MS medium containing $0.3 \mathrm{M}$ sucrose. After 2 days, the meristem clumps were transferred onto regeneration medium. The first week of culture was always in the dark.

\section{Control treatment and meristem culture}

Two control treatments were initiated to allow the comparison of virus eradication following cryopreservation protocols with more traditional virus eradication techniques.

\section{Control treatment - clumps of meristems $(C C)$}

Proliferating clumps containing several meristem tips were regenerated on MS semi-solid medium supplemented with $1 \mu M$ BA and $1 \mu M$ IAA (regeneration medium)

\section{Control treatment - single meristems $(\mathrm{Cm})$}

Individual meristem tips of 1-mm diameter were excised under a binocular microscope from actively proliferating meristems and regenerated as described for CC.

\section{Plant regeneration}

Shoots produced at the end of each assay were rooted on MS medium supplemented with $0.5 \mathrm{~g} / \mathrm{l}$ active charcoal.

Virus screening

The health status of regenerated material was initially checked on in vitro plants by DAS-ELISA using the Loewe kit (Biochemica $\mathrm{GmbH}$ ) for CMV and by TAS-ELISA for BSV (Ndowora and Lockhart 2000) using IgG kindly provided by Dr. B. Lockhart (University of Minnesota, USA). The cut off value for the threshold was 0.2 absorbance units. The putative virus-free material was then tested a second time as part of an international accepted practice after a greenhouse acclimatisation phase of 6 months (Diekman and Putter 1996).

The eradication rate (ER) observed in fine for each treatment was calculated as follows.
1. After the first ELISA test performed on in vitro plants:

$\mathrm{ER}=\left(\frac{\text { negative in vitro plants }}{\text { tested in vitro plants }}\right) \times 100$

2. After the second ELISA test performed on in vivo plants:

$$
\begin{aligned}
\mathrm{ER}= & \left(\frac{\text { negative in vitro plants }}{\text { tested in vitro plants }}\right) \\
& \times\left(\frac{\text { negative in vivo plants }}{\text { tested in vivo plants }}\right) \times 100
\end{aligned}
$$

Light microscopy

Chemical fixation of actively proliferating meristem clumps or excised meristems was performed using a $2.5 \%$ glutaraldehyde [in $0.1 M$ phosphate buffer ( $\mathrm{pH}$ 7.2)] solution. After vacuum had been applied three times, 5 min each time, in a desiccator, samples were kept overnight at $4{ }^{\circ} \mathrm{C}$ and post-fixed with a $1 \%$ osmic acid [in $0.1 M$ phosphate buffer ( $\mathrm{pH} 7.2$ )] solution. The samples were then dehydrated through an incremental ethanol series $(50 \%, 70 \%, 85 \%$ and $95 \%$ ) in a $0.85 \%$ saline solution ( $1 \mathrm{~h}$ on ice for each ethanol dilution) and stored in $100 \%$ ethanol (overnight at $4^{\circ} \mathrm{C}$ ). After dehydration, the samples were embedded in a mould filled with Epon 812 resin and kept in an oven for 3-4 days at $60^{\circ} \mathrm{C}$ for polymerisation. Thin sections were cut on a Pyramitome ${ }^{\circledR} 11800$ apparatus (LKB Bromma) with glass knives and stained with toluidine blue. The sections were observed with a light microscope Olympus AX 70.

\section{Results and discussion}

In banana and plantain, meristem culture is considered to be the reference tool for virus eradication. For example, both Berg and Bustamante (1974) and Gupta (1986) reported mosaic disease eradication based on meristem culture alone or combined with thermotherapy. To date, no study has been reported for BSV. Meristem culture in combination with thermotherapy is very time-consuming. Brison et al. (1997) reported on the use of cryopreservation for Plum Pox Virus elimination from plum rootstocks and compared it to traditional eradication methods like meristem culture, observing $50 \%$ and $20 \%$ virus-free plants after regeneration from frozen shoot tips or meristem-tip culture, respectively.

To evaluate the efficiency of cryotherapy for virus eradication in Musa, we used actively proliferating meristems of banana (Fig. 1b) instead of excised meristems since very low post-cooling regeneration rates have been reported for the latter (Panis et al. 1998). Light microscopic observations performed on actively proliferating meristem sections showed that meristematic domes were not protected by leaf primordia (Fig. 1c) while a single meristem excised from rooted in vitro plantlets was so protected (Fig. 1d). The absence of a primordium may facilitate the penetration of the cryoprotective PVS-2 solution and its subsequent dehydration effect. Moreover, the air bubble that is enclosed between the dome and the leaf primordia can function as thermic isolation, thereby slowing the rate of freezing. Thus, the cryopreservation of proliferating meristems resulted in a regrowth of about $50 \%$ but with the growth being delayed in comparison to the control (Fig. 2a, b). Moreover, plants regenerated 

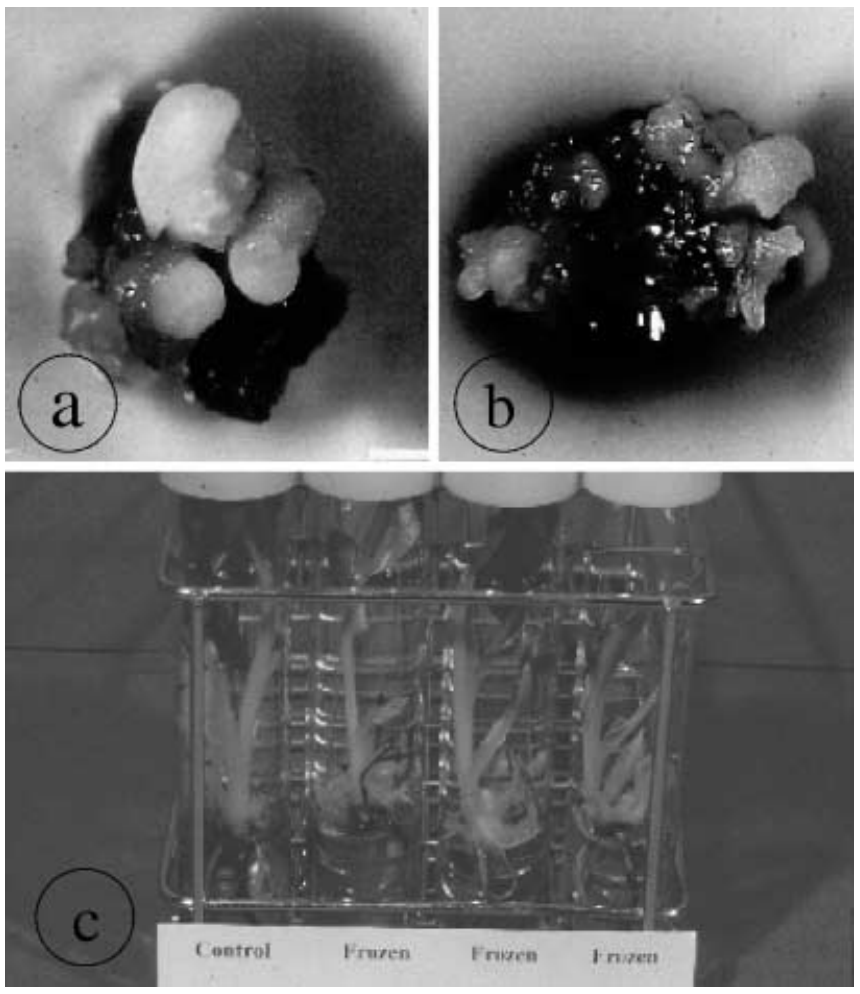

Fig. 2 Control clump a of a highly proliferating meristem (cv. Williams ITC. 0570) compared to a frozen clump that shows delayed regeneration b 2 weeks after reculture. c Plantlets obtained after the regeneration of control clumps (control) and frozen clumps (frozen) showing no morphological differences

after cryopreservation showed no morphological differences compared to the control plantlets (Fig. 2c).

Plants regenerated after in vitro multiplication of highly proliferating meristem cultures (CC) gave a spontaneous virus eradication rate of 3\% (3 plantlets out of 96 tested) and 59\% (44 plantlets out of 75 tested) for CMV (Fig. 3a) and for BSV (Fig. 3b), respectively, after the first test. The state of health of the plants was stable when tests were performed a second time on in vivo plants that had been acclimated in the greenhouse for 6 months. The difference in the spontaneous eradication rates between CMV and BSV may possibly be explained by their heterogeneous distribution and by a difference in the concentration of viral particles in the meristem tip. Immunolocalisation of the viral particles is currently being carried out to examine this hypothesis.

The percentage of healthy in vitro plantlets was $0 \%$ (0 plantlets out of 8 tested) and 76\% (53 plantlets out of 70 tested) for CMV and BSV, respectively; for the material regenerated after meristem culture $(\mathrm{Cm})$, similar values were obtained after the second test performed on in vivo plants. The lack of elimination of CMV confirmed the previous result obtained by Berg and Bustamante (1974) who observed mosaic disease symptoms on 11 indicator plants following inoculation with an extract of Cavendish banana plants regenerated after meristem-tip culture. The application of meristem-tip

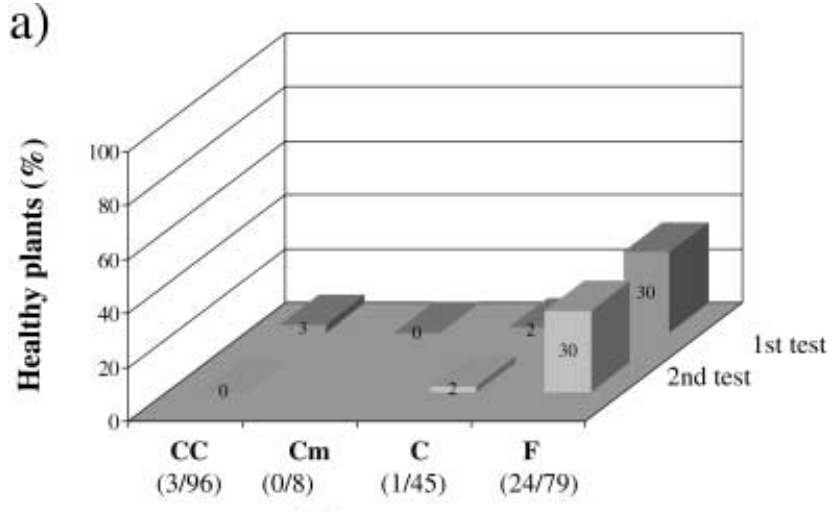

Treatment

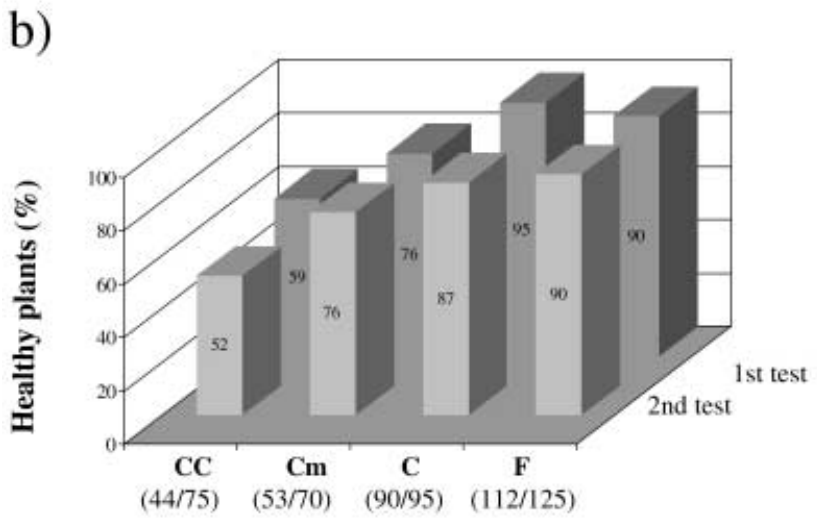

Treatment

Fig. 3 Eradication rates for CMV- a and BSV- $\mathbf{b}$ infected plants obtained after the ELISA test on in vitro plants (first test) and in vivo plants (second test). The number in brackets indicates the number of negative plantlets per total plantlets. $C C$ Plantlets after direct regeneration from highly proliferating meristems, $\mathrm{Cm}$ plantlets regenerated from individual meristems excised from highly proliferating meristem, $C$ plantlets regenerated after a 1-h cryoprotection in PVS-2 solution, $F$ plantlets regenerated directly after cryopreservation

culture to eradicate viral particles was initially based on the concept of meristem "immunity" towards viruses (Morel 1948). Different researchers have shown that the probability of obtaining virus-free plants is inversely related to the size of the meristem (Faccioli and Marani 1998). However, the reason why the meristematic dome fails to support virus growth is quite unknown. Matthews (1991) suggested that in dividing cells, the plant mRNAs that are present in high concentrations in active cells might compete effectively with viral RNAs for the translation apparatus. Alternatively, cell-to-cell movement proteins are unable to function in meristematic cells due to their lack of selectivity for the sequence of nucleic acid they transport (Hake and Char 1997). Moreover, the size and the number of plasmodesmata increase with respect to their location distally from the meristematic cell. This would improve cell-to-cell virus translocation in the distal region. However, the capability of the meristem to develop into a full plant is directly related to the size of the explant. Hence, a compromise needs to 


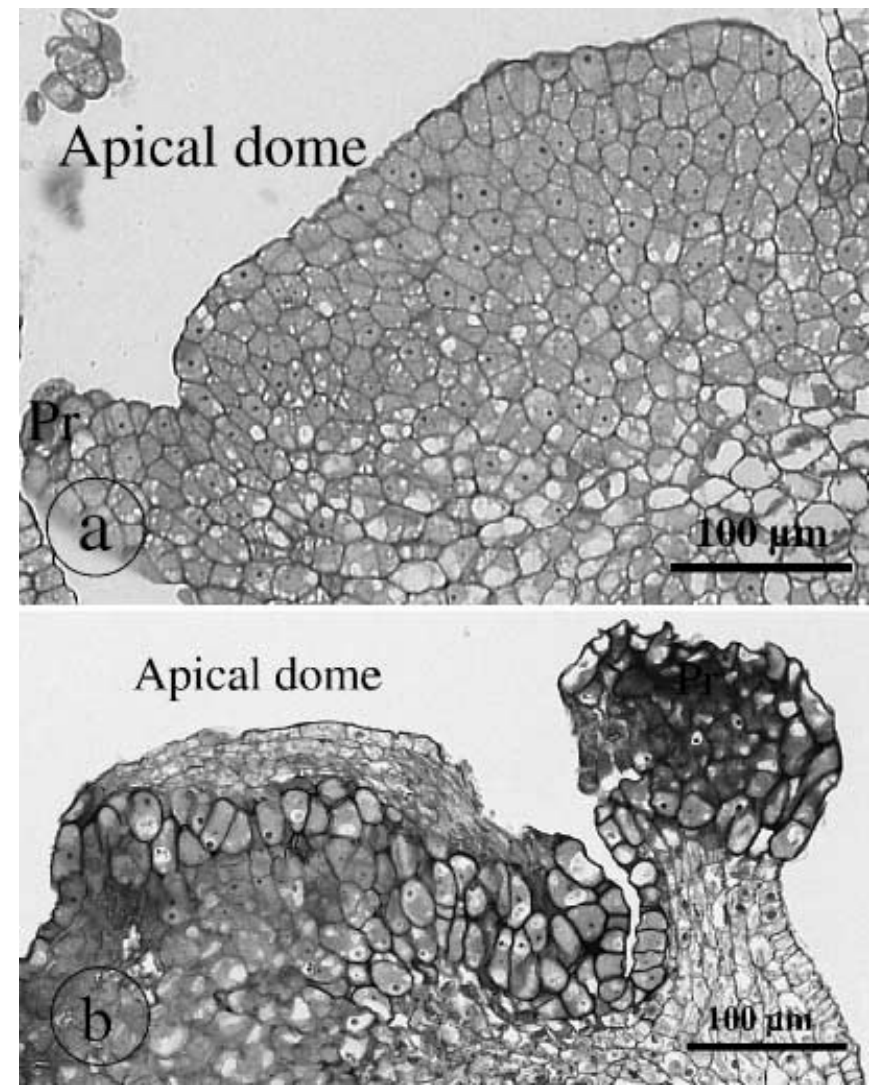

Fig. 4a, b Light microscopy of meristem excised from highly proliferating meristems before or after cryotherapy. Protocol: 2-week preculture on MS medium supplemented with $0.4 M$ sucrose $+2 \mathrm{~h}$ of cryoprotection in PVS-2 solution, subsequent cooling to LN temperature, held $1 \mathrm{~h}$ in $\mathrm{LN}$, then warmed and regenerated for 1 week on MS medium. a Top of a non-cryopreserved meristem, b small areas of surviving cells on the top of a cryopreserved meristem tip; surviving cells were recognised by dense nucleoli in nuclei located in well-preserved cytoplasma. Pr Primordium

be found for successful virus elimination and for plant development.

After a 1-h cryoprotection with PVS-2 solution, only 1 out of the 45 plants tested (2\%) for CMV and 90 out of the 95 plants tested (95\%) for BSV were virus-free. The eradication rate of BSV decreased to $87 \%$ following greenhouse acclimation, while CMV eradication rate remained constant. The ultrastructural study performed (results not shown) showed injuries induced by the cryoprotective solution on the meristematic cells combined with an uneven distribution of viral particles in the meristem could explain this effect.

After cryopreservation, 30\% (24 plantlets out of the 79 tested) and $90 \%$ (112 plantlets out of 125 tested) of the regenerated plants were virus-negative for CMV and BSV, respectively, after acclimation in the greenhouse.

To understand the mode of action of cryopreservation, we made structural observations on cryopreserved highly proliferating meristems and compared them with control meristems (Fig. 4). Meristematic cells are characterised by their small size (approx. $15 \mu \mathrm{m}$ in length) and by a high nucleo-cytoplasm ratio that is typical of actively dividing cells (Fig. 4a). This nucleo-cytoplasm ratio decreased progressively with increasing distance from the meristematic dome. The nucleolus was very distinct in the rounded nucleus located in dense cytoplasm containing many small vacuoles.

After 1 week of recovery following the cryotherapy, severe abnormalities were observed in many cells (Fig. 4b). The localisation of damaged cells indicated that freezing injuries were generally linked with increased vacuolisation. In fact, freezing injury is reported to be mainly the result of intracellular water crystallisation, which occurs either during the cooling and/or the thawing steps. Thus, small areas of surviving cells were identified in primordial leaf tissues and in the tunica of the meristematic dome. The recovering cells were similar to those of the control (Fig. 4a). These small areas of surviving cells, previously shown by Helliot (1998) on cryopreserved meristems of plum, kept their capacity for active cell division and structural organisation leading to regeneration into whole plants (Haskins and Kartha 1980).

Light microscopy showed that cryopreservation acted as a micro-scalpel - it kept alive a few layers of meristematic cells but killed the more hydrated parenchymatic cells. If such ultra-thin sections of banana meristems were excised with a scalpel, they would immediately blacken and die due to the oxidation of polyphenols. Thus, the main difference between cryotherapy and meristem culture lies in the number of meristematic cell layers that survive. This, in combination with the putative localisation of the virus within the meristem, could explain the relatively high CMV and BSV eradication rates obtained after the cryopreservation of proliferating meristem clumps. An ultrastructural study of highly proliferating meristems of banana at each step of the cryopreservation process would provide the information necessary to understand the mode of action of cryotherapy at the cellular level. Moreover, immunolocalisation of viral particles in the meristem, currently being evaluated in our laboratory, will provide supplementary knowledge on the eradication process by cryotherapy.

In conclusion, cryopreservation seems to be a very promising technique for virus eradication from Musa in the context of germplasm preservation and international diffusion. It avoids the time-consuming meristem excision and the consequent problem of blackening due to polyphenol oxidation. However, in the case of banana varieties with forms of BSV integrated into their genome that are capable of being activated, the eradication of viral particles obtained by cryotreatment could be counterbalanced by the activation of these integrated sequences induced by the cryoprocedure and/or by the in vitro procedure. Indeed, Ndowora et al. (1999) reported the existence of viral sequences within the genome of Musa cultivars and hybrids that can give rise to episomal viral infection as a result of in vitro culture. 
Acknowledgements We would like to thank A. Locicero (FUSAGx, Belgium) and K. Reyners (K.U. Leuven, Belgium), respectively, for their kind help in virus detection and cryopreservation. The current study was performed in the framework of an INIBAP (International Network for the Improvement of Banana and Plantain) project entitled "Development of in vitro culture techniques for virus diseases elimination from Musa" (Helliot et al. 2001) and was largely supported with funding provided by the Directorate General for International Cooperation (DGIC, Belgium). This work is part of the global PROMUSA program.

\section{References}

Berg LA, Bustamante M (1974) Heat treatment and meristem culture for the production of virus-free bananas. Phytopathology 64: 320-322

Brison M, de Boucaud MT, Pierronnet A, Dosba F (1997) Effect of cryopreservation on the sanitary state of a cv. Prunus rootstock experimentally contaminated with Plum Pox Potyvirus. Plant Sci 123:189-196

Daniells J, Jenny C, Karamura D, Tomekpe K (2001) Williams, cultivated varieties AAA. In: Arnaud E, Sharrock S (eds) Musalogue: a catalogue of Musa germplasm - diversity in the genus Musa. INIBAP, Montpellier, France, p 67

Diekmann M, Putter CAJ (1996) FAO/IPGRI technical guidelines for the safe movement of germplasm, no.15: Musa. Food and Agriculture Organization of the United Nations, Rome/ International Plant Genetic Resources Institute, Rome

Faccioli G, Marani F (1998) Virus elimination by meristem tip culture and tip micrografting. In: Hadidi A, Khetarpal RF, Koganezawa H (eds) Plant virus diseases control. APS Press, St Paul, Minn. pp 346-380

Frison EA, Sharrock S (1999) The economic, social and nutritional importance of banana in the world. In: Picq C, Fouré E, Frison EA (eds) Banana and food security. INIBAP, Montpellier, France, pp 21-35

Gupta PP (1986) Eradication of mosaic disease and rapid clonal multiplication of bananas and plantains through meristem tip culture. Plant Cell Tissue Organ Cult 6:33-39

Hake S, Char BR (1997) Cell-cell interactions during plant development. Genes Dev 11:1087-1097

Harper G, Osuji JO, Heslop-Harrison JS, Hull R (1999) Integration of Banana Streak Badnavirus into the Musa genome: molecular and cytogenetic evidence. Virology 255:207-213

Haskins RH, Kartha KK (1980) Freeze preservation of pea meristems: cell survival. Can J Bot 58:833-840
Helliot B (1998) Croissance et Stabilité génétique des Vitroplants de Prunier Ferlenain Plumina (R) après cryoconservation des méristèmes. PhD thesis, no. 2014, University of Bordeaux 1, France

Helliot B, Panis B, Locicero A, Reyniers K, Muylle H, Vandewalle M, Michel C, Swennen R, Lepoivre P (2001) Development of in vitro culture techniques for virus diseases elimination from Musa. In: 4th Int Symp In Vitro Cult Hortic Breed. Acta Hortic 560:535-538

Hu JS, Li HP, Barry K, Wang M (1995) Comparison of dot blot, ELISA and RT-PCR assays for detection of two cucumber mosaic virus isolates infecting banana in Hawaï. Plant Dis 79: 902-906

Lockhart BEL, Jones DR (2000) Banana mosaic and banana streak, diseases caused by viruses. In: Jones DR (ed) Diseases of banana, Abaca and Enset. CAB Int, Wallingford, UK, pp 241-293

Lockhart BEL, Olzewski NE (1993) Serological and genomic heterogeneity of banana streak badnavirus: implication for virus detection in Musa germplasm. In: Ganry J (ed) Breeding banana and plantain for resistance to diseases and pests. Proc Int Symp Genet Improvement Bananas Resistance Dis Pests. CIRAD-FLHOR, Montpellier, France pp 105-113

Matthews REF (1991) Transmission, movement and host range. In: Matthews REF (ed) Plant virology, 3rd edn. Academic/ Harcourt Brace Jovanovich, San Diego, pp 358-371

Morel G (1948), Recherches sur la culture associée de parasites obligatoires et de tissus végétaux. Ann Epiphyt 1:123-234

Murashige T, Skoog F (1962) A revised medium for rapid growth and bioassays with tobacco tissues cultures. Physiol Plant 15: 473-497

Ndowora TCR, Lockhart BEL (2000) Development of a serological assay for detecting serologically diverse banana Streak virus isolates. Acta Hortic 540:377-388

Ndowora TCR, Dahal G, Lafleur D, Harper G, Hull R, Olszewski NE, Lockhart BEL (1999) Evidence that Badnavirus infection in Musa can originate from integrated pararetroviral sequences. Virology 255:214-220

Panis B, Totte N, Van Nimmen K, Withers L, Swennen R (1996) Cryopreservation of banana (Musa spp.) meristems cultures after preculture on sucrose. Plant Sci 21:95-106

Panis B, Schoofs H, Thinh NT, Swennen R (1998) Cryopreservation of proliferating meristem cultures of banana. In: Engelmann F, Takagi H (eds) Cryopreservation of tropical plant germplasm, current research progress and applications. Proc JIRCAS/ IPGRI Joint Int Workshop. IPGRI, Rome, pp 238-243

Sakaï A, Kobayashi S, Oiyama I (1990) Cryopreservation of nucellar cells of navel orange (Citrus sinensis Obs. var. Brasiliensis tanaka) by vitrification. Plant Cell Rep 9:30-33 